\title{
Iron, folate and vitamin B12 levels in first trimester pregnancies in the Southwest region of Turkey
} Türkiye'nin güneybatı bölgesinde I.trimester gebelerde demir, folat ve vitamin B12
düzeyleri

\author{
Aysun Karabulut ${ }^{1}$, Osman Şevket ${ }^{1}$, Ayhan Acun ${ }^{2}$ \\ 'Clinic of Obstetrics and Gynecology, Denizli State Hospital, Denizli, Turkey \\ ${ }^{2}$ Department of Biochemistry, Denizli State Hospital, Denizli, Turkey
}

Abstract

Objective: Iron, folate and vitamin B12 play important roles in the healthy development of the fetus in pregnancy. Preconceptional levels of these micronutrients is influenced by dietary habits. The purpose of this study was to investigate the status of iron, vitamin B12 and folate in first trimester pregnancies in the southwest region of Turkey where the Mediterranean Cuisine, rich in fresh fruit and vegetables is commonly consumed.

Material and Methods: Two hundred and one low-middle income pregnant women were recruited during their first prenatal visit. Hemoglobin, ferritin, folate and vitamin B12 levels were evaluated and a structured questionnaire was given to gather information including age, gravida, parity, frequency of pregnancy, history of abortion, and intrauterine device usage. Based on WHO and international guidelines, anemia was defined as hemoglobin $<11 \mathrm{~g} / \mathrm{dl}$, and iron deficiency as ferritin $<15 \mu \mathrm{g} / \mathrm{L}$. Serum folate and vitamin B12 deficiencies were defined as levels below $3 \mathrm{ng} / \mathrm{ml}$ and $200 \mathrm{pg} / \mathrm{ml}$ respectively.

Results: The mean age and gestational week were $26.4 \pm 5.3$ years and $9 \pm 3$ weeks respectively. Mean plasma concentrations were $12.8 \pm 9.7 \mathrm{~g} / \mathrm{dl}$ for hemoglobin, $22.7 \pm 17.2 \mu \mathrm{g} / \mathrm{L}$ for ferritin, $12.2 \pm 5.6 \mathrm{ng} /$ $\mathrm{ml}$ for folate and $266.6 \pm 100.2 \mathrm{pg} / \mathrm{ml}$ for vitamin B12. Anemia was detected in $4.5 \%$ of pregnant women, iron deficiency in $40.3 \%$, vitamin B12 deficiency in $29.8 \%$ and folate deficiency in $0.5 \%$ of patients. In $10.9 \%$ of patients, both vitamin B12 and iron iron deficiency was detected. There was no significant difference for age, body mass index, gravida, parity, frequency of pregnancy, history of abortion, and intrauterine device usage between women with low and normal levels of vitamin B12 and Ferritin ( $\mathrm{p}>0.05)$.

Conclusion: Iron and vitamin B12 deficiencies were relatively common in the pregnant population consuming vegetable based diets. Iron and vitamin B12 supplementation in addition to folate must be considered for the wellbeing of the fetus in pregnant women living in areas where dietary patterns are mainly vegetable based.

(J Turkish-German Gynecol Assoc 2011; 12: 153-6)

Key words: Hemoglobin, ferritin, folate, vitamin B12, pregnancy

Received: 19 April, 2011
Accepted: 19 July, 2011
Özet

Amaç: Gebelikte demir, folat ve vitamin B12 düzeyleri fetusun sağlıklı gelişiminde önemli rol oynamaktadır. Bu mikroelementlerin gebelik öncesi serum düzeyleri beslenme alışkanlıklanı ile yakından ilişkilidir. Bu çalışmada, taze meyve ve sebzenin yoğun olarak tüketildiği, akdeniz mutfağının yayğın olduğu Türkiye'nin güney batı bölgesinde, I.trimester gebelerde serum demir, folat ve vitamin B12 düzeylerini incelemeyi amaçladık.

Gereç ve Yöntemler: I. Trimesterde başvuran, düşük-orta gelir grubunda 201gebe çalışmaya alındı. Hemoglobin, ferritin, folate ve vitamin B12 seviyeleri ölçüldü. Sorgulama formu sunularak yaş, gravida, parite, gebelik sıklığı, düşük hikayesi ve rahim içi araç kullanımı hakkında bilgi toplandı. Dünya sağlık örgütü ve uluslar arası yönergelere dayanılarak hemoglobin düzeyinin $<11 \mathrm{~g} / \mathrm{dl}$ olması anemi ve ferritin düzeyinin $<15 \mu \mathrm{g} / \mathrm{L}$ olması demir eksikliği olarak değerlendirildi. Serum folate and vitamin B12 için sırasıyla $3 \mathrm{ng} / \mathrm{ml}$ ve $200 \mathrm{pg} / \mathrm{ml}$ 'nin altındaki değerler eksiklik olarak kabul edildi.

Bulgular: Ortalama gebelik haftası $9 \pm 3$ hafta ve ortalama yaşı $26.4 \pm 5.3$ yll idi. Ortalama hemoglobin düzeyi $12.8 \pm 9.7 \mathrm{~g} / \mathrm{dl}$, Ferritin düzeyi $22.7 \pm 17.2 \mu \mathrm{g} / \mathrm{L}$, folate düzeyi $12.2 \pm 5.6 \mathrm{ng} / \mathrm{ml}$ ve vitamin B12 düzeyi $266.6 \pm 100.2 \mathrm{pg} / \mathrm{ml}$ olarak saptandı. Gebelerin \%4.5'inde anemi, \%40.3'ünde demir eksikliği, \%29.8'inde vitamin B12, \%0.5'inde folate eksikliği, \%10.9'unda ise hem vitamin B12 hem de demir eksikliği tespit edildi. Ferritin ve vitamin B12 düzeyleri düşük ve normal olan gruplar arasında yaş, vücut kitle endeksi, gravida, parite, gebelik sıklığı, düşük hikayesi ve rahim içi araç kullanımı açısından istatistiksel olarak anlamlı bir fark saptanmadı ( $\mathrm{p}>0.05)$.

Sonuç: Demir ve vitamin B12 eksikliği, sebze ağırlıklı beslenen bu bölgede folat eksikliğine göre daha yaygındı. Beslenme alışkanlığının sebze ağırlıklı olduğu bölgelerde yaşayan gebelerde sağlıklı fetal gelişim için erken gebelikte folat suplementasyonuna, demir ve vitamin B12 içeren preparatların da eklenmesi düşünülmelidir.

(J Turkish-German Gynecol Assoc 2011; 12: 153-6)

Anahtar kelimeler: Hemoglobin, ferritin, folat, vitamin B12, gebelik Geliş Tarihi: 19 Nisan 2011

Kabul Tarihi: 19 Temmuz 2011 


\section{Introduction}

Iron deficiency is the most commonly detected nutritional deficiency in pregnant women. It was postulated to be associated with poor pregnancy outcome and preterm delivery (1). During pregnancy, there is a significant increase in iron requirements due to increased red cell mass and fetoplacental growth (1). Diet is also an important factor determining the preconceptional iron status in the reproductive age group.

Preconceptional supplementation of folic acid has been shown to reduce neural tube defects (NTD) in the fetus (2). Although some countries introduced folic acid fortification programs in time, fetal NTD still continues to affect about 6 in every 10,000 pregnancies $(2,3)$. There are probably other modifiable risk factors contributing to the prevalence of NTD.

Vitamin B12 shows close metabolic association with folate. It has been demonstrated that the deficiency of vitamin B12 may be an independent risk factor, almost triplicating the risk of NTD $(4,5)$. Vitamin B12 includes a group of cobalt-containing compounds known as cobalamins. This vitamin is involved in myelin synthesis, fatty acid degradation, and protein and DNA synthesis (6). All the natural vitamin B12 is produced by microorganisms and it is only found in foods of animal origin and vegetables contaminated with vitamin B12-synthesizing bacteria. Vitamin B12 is an animal source vitamin and deficiency is common in vegetarians due to low intake and in the elderly due to low absorption (7). Therefore vegetable based diets may lead to vitamin B12 deficiency.

In this study, we aimed to investigate the status of iron, vitamin B12 and folate in first trimester pregnancies in the southwest region of Turkey where a vegetarian based diet referred to as Mediterranean Cuisine is in common use.

\section{Materials and Methods}

This prospective study was carried out between January 2010 and June 2010. The study population was composed of patients attending the ambulatory pregnancy Clinic. The pregnant women admitted to hospital for routine obstetrical evaluation in the first trimester of pregnancy, who had not initiated any kind of vitamin preparation and had no history of neural tube defect were included in the study. Patients; (i) on vegetarian diet, (ii) with multiple pregnancies, (iii) previous history of anemia, renal disease and alcohol consumption, (iv) evidence of malabsorption, (v) BMI below $18.5 \mathrm{~kg} / \mathrm{m}^{2}$ and (vi) smoking patients were excluded. The study population was composed of low-middle income patients according to an income and living conditions survey of the Turkish statistical institude (8). A structured questionnaire was given to gather information including age, parity, time of previous gestation, and the history of intrauterine device (IUD) usage. Weight and height of the subjects were obtained to calculate body mass index (BMI). Blood specimens from all subjects were obtained with a standard venopuncture technique after 8 to 10 hours of fasting. Based on WHO and international guidelines, anemia was defined as hemoglobin $<11 \mathrm{~g} / \mathrm{dl}$, and iron deficiency as ferritin $<15 \mu \mathrm{g} / \mathrm{L}$. Serum folate and vitamin B12 deficiencies were defined as levels below $3 \mathrm{ng} / \mathrm{ml}$ and $200 \mathrm{pg} / \mathrm{ml}$ respectively. A hemoglobin measurement was performed via Photometric assay (Abbott Cell-Dyn 3700, Abbott Laboratories Abbott Park IL, USA). Ferritin, vitamin B12 and folate measurements were performed using the chemiluminescence assay (Siemens ADVIA Centaur® immunoassay, Tarry town, NY, USA).

The procedures were explained to all subjects and written informed consent was obtained. The study protocol conformed to the ethical guidelines of the Declaration of Helsinki, as reflected in a prior approval by the institution's human research committee.

Continuous variables were expressed as mean \pm standard deviation (SD). To analyze the differences between groups, the independent student $t$ test was used for continuous variables, and chi square test was used for nominal variables. Statistical analysis was performed using the statistical package for Social Sciences (SPSS 15.0, Chicago, IL) software. P values less than 0.05 were considered statistically significant.

\section{Results}

Two hundred and one patients out of 249 low-middle income women were recruited for the study. Forty eight patients were excluded from the study, since they had already started vitamin pills before admission. The mean age and gestational week of the study population were $26.4 \pm 5.3$ years and $9 \pm 3$ weeks respectively (Table 1). Of 201 subjects, anemia was detected only in nine (4.5\%) women according to WHO criteria. However, iron deficiency was seen in 82 (40.3\%) women (Table 2). There was no significant difference for age, body mass index, gravida, parity, frequency of pregnancy, history of

Table 1. Characteristics of the study population

\begin{tabular}{|l|c|c|c|}
\hline & Mean \pm SD & Minimum & Maximum \\
\hline Age (year) & $26.4 \pm 5.3$ & 17 & 42 \\
\hline BMI $\left(\mathrm{kg} / \mathrm{m}^{2}\right)$ & $23.9 \pm 4.3$ & 15 & 38 \\
\hline Gestational Age (week) & $9 \pm 3$ & 5 & 14 \\
\hline Gravida & $1.5 \pm 1.2$ & 0 & 9 \\
\hline Parity & $0.8 \pm 0.9$ & 0 & 5 \\
\hline $\begin{array}{l}\text { Time from last } \\
\text { pregnancy (year) }\end{array}$ & $4.9 \pm 3.1$ & 1 & 20 \\
\hline
\end{tabular}

Table 2. Hemoglobin, ferritin, vitamin B12 and folate concentrations and percentage of women with abnormal values

\begin{tabular}{|l|c|c|c|c|}
\hline & Mean \pm SD & Minimum & Maximum & Abnormal $^{\mathbf{1}}$ (\%) \\
\hline $\begin{array}{l}\text { Hemoglobin } \\
(\mathrm{g} / \mathrm{dl})\end{array}$ & $12.8 \pm 9.7$ & 8.7 & 14.9 & 4.5 \\
\hline $\begin{array}{l}\text { Ferritin } \\
(\mu \mathrm{g} / \mathrm{L})\end{array}$ & $22.7 \pm 17.2$ & 1.6 & 93.5 & 40.5 \\
\hline $\begin{array}{l}\text { Vitamin B12 } \\
\text { (pg/ml) }\end{array}$ & $266.6 \pm 100.2$ & 30.0 & 593.0 & 29.6 \\
\hline $\begin{array}{l}\text { Folic acid } \\
(\mathrm{ng} / \mathrm{ml})\end{array}$ & $12.2 \pm 5.6$ & 3.4 & 24.0 & 0.5 \\
\hline
\end{tabular}

${ }^{1}$ Abnormal is defined as hemoglobin level $<11 \mathrm{~g} / \mathrm{dl}$, ferritin level $<15 \mu \mathrm{g} / \mathrm{L}$, vitamin $\mathrm{B} 12<200 \mathrm{pg} / \mathrm{ml}$, folate $<3 \mathrm{ng} / \mathrm{ml}$ 
abortion, and intrauterine device usage between women with low and normal ferritin levels ( $p>0.05)$ (Table 3). Vitamin B12 deficiency was present in $60(29.8 \%)$ patients, whereas folate deficiency was detected only in one patient (Table 2). There was no significant difference in age, body mass index, gravida, parity, frequency of pregnancy and history of abortion and intrauterine device usage between women with low and normal vitamin B12 levels ( $\mathrm{p}>0.05)$ (Table 4).

In 22 (10.9\%) women, both iron and vitamin B12 deficiency was detected. $\mathrm{Fe}^{+2}$ sulphate (Gynoferon ${ }^{\circledR}$ tb, Koçak Farma, Istanbul, Turkey) $80 \mathrm{mg}$ orally per day and cyanocobalamin $1000 \mu \mathrm{g}$ (Dodex ${ }^{\circledR}$ amp., Deva, Istanbul, Turkey) every other day were added to the treatment for ferritin and vit. B12 deficiency. For folate deficiency, $5 \mathrm{mg}$ folic acid (Folbiol ${ }^{\circledR}$ tb, I.E. Ulugay, Istanbul Turkey) perday was prescribed to the patient.

\section{Discussion}

Dietary habit is an important factor determining the micronutrient status of our body and it shows great variation according to cultural factors and geographical regions. The United Nations (UN) estimates that approximately half of pregnant women suffer from anemia worldwide (9). Anemia prevalence during pregnancy differed from $18 \%$ in developed countries to $75 \%$ in

Table 3. Comparison of demographic characteristics of patients with low and normal ferritin levels

\begin{tabular}{|l|c|c|c|}
\hline & $\begin{array}{c}\text { Group with low } \\
\text { ferritin level } \\
(\mathbf{N}=\mathbf{8 2})\end{array}$ & $\begin{array}{c}\text { Group with normal } \\
\text { ferritin level } \\
(\mathbf{N}=1 \mathbf{1 9})\end{array}$ & p value \\
\hline Age (year) & $26.7 \pm 5.5$ & $26.2 \pm 5.1$ & NS \\
\hline BMI (kg/m²) & $23.4 \pm 5.3$ & $22.8 \pm 4.9$ & NS \\
\hline $\begin{array}{l}\text { Gestational Age } \\
\text { (week) }\end{array}$ & $7.2 \pm 4.1$ & $7.7 \pm 3.5$ & NS \\
\hline Gravida & $1.5 \pm 0.9$ & $1.4 \pm 1.3$ & NS \\
\hline Parity & $0.8 \pm 0.8$ & $0.8 \pm 0.7$ & NS \\
\hline $\begin{array}{l}\text { Time from last } \\
\text { pregnancy (year) }\end{array}$ & $2.9 \pm 3.8$ & $2.7 \pm 3.2$ & NS \\
\hline NS; Nonspecific & & & \\
\hline
\end{tabular}

Table 4. Comparison of demographic characteristics of patients with low and normal vitamin B12 levels

\begin{tabular}{|l|c|c|c|}
\hline & $\begin{array}{c}\text { Group with low } \\
\text { vitB12 level } \\
(\mathbf{N}=\mathbf{6 0})\end{array}$ & $\begin{array}{c}\text { Group with normal } \\
\text { vitB12 level } \\
(\mathbf{N}=141)\end{array}$ & p value \\
\hline Age (year) & $25.9 \pm 5.26$ & $26.4 \pm 5.26$ & NS \\
\hline BMI (kg/m²) & $22.4 \pm 5.3$ & $23.1 \pm 3.4$ & NS \\
\hline $\begin{array}{l}\text { Gestational Age } \\
\text { (week) }\end{array}$ & $8.5 \pm 3.6$ & $8.2 \pm 3.5$ & NS \\
\hline Gravida & $1.4 \pm 0.9$ & $1.5 \pm 1.3$ & NS \\
\hline Parity & $0.9 \pm 0.8$ & $0.8 \pm 0.9$ & NS \\
\hline $\begin{array}{l}\text { Time from last } \\
\text { pregnancy (year) }\end{array}$ & $2.9 \pm 2.9$ & $2.7 \pm 3.5$ & NS \\
\hline NS; Nonspecific & & \\
\hline
\end{tabular}

South Asia (10). Nutrition related iron deficiency is the main cause of anemia throughout the world (9). Iron deficiency and anemia during pregnancy is a global problem and is closely related with maternal and perinatal mortality (10). The high prevalence of deficiencies detected in the first trimester of pregnancy poses particular reproductive risks. In the present study, $40.3 \%$ of women had depleted iron stores and $4.5 \%$ had iron deficiency anemia. In a similar study conducted in Marmara region, low levels of Ferritin were detected in 52.3\% of first trimester pregnancies (11). Karaoglu et al. detected a prevalence of iron deficiency and anemia higher as; $57 \%$ and $27.1 \%$ respectively in East Anatolia (12). In contrast to the present study, second and third trimester pregnancies were evaluated in that study. This high rate in the previous study can be attributed to the fact that anemia is more prevalent after the first trimester of pregnancy due to increased metabolic demands and physiologic hemodilution.

The first trimester pregnancies without any supplementation more likely reflect the preconceptional status. Our results emphasize that, although anemia is not a major problem, iron deficiency is a common problem in this geographical region. These patients will probably develop iron deficiency anemia with the progression of pregnancy. Screening in the preconceptional period or early pregnancy seems valuable for the detection and treatment of iron deficiency and anemia.

Both folate and cobalamin deficiencies are characterized by megaloblastic anemia and elevated blood homocysteine levels, which lead to cardiovascular problems and adverse pregnancy outcomes, such as recurrent abortion and preeclampsia (13-16). It has been hypothesized that both folate and vitamin B12 could have a crucial role in folate-related NTD (17). High prevelances of deficiencies may also be seen in countries with different socioeconomic classes. A Canadian study performed in 2000 showed that the prevalence of folic acid and vitamin B12 deficiencies in pregnant women was $27 \%$ and $44 \%$ respectively (18). The same prevalences were detected as $36 \%$ and $61 \%$ for folate and vitamin B12 deficiencies respectively in Venezuela (19). In a study from Turkey, Ackurt et al. detected low levels of vitamin B12 and folate in $48.8 \%$ and $59.7 \%$ of subjects respectively among first trimester pregnant women in the Marmara region (11). In our study, low vitamin B12 levels were detected in 60 patients (30\%), but low folate level was detected only in one patient. Although the regional nutritional habit is mainly vegetable based, none of the women were vegetarians and all the women included in the study implied that they ate meat. They were consuming meat, but the amount was probably insufficient. This results in iron and vitamin $\mathrm{B} 12$ deficiency.

Low folic acid levels were shown to be associated with increased NTD. Although there are no studies showing the prevalence of NTD in Denizli, two studies from Izmir and another city in the Aegean region sharing similar nutritional habits showed a relatively lower NTD risk compared to the northern and eastern parts of Turkey. Posaci et al. (20) and Caglayan et al. (21) found NTD in 1.5 and 1.9 per 1000 pregnancies in the Izmir region, whereas the same rates were detected as 4.4 and 5.6 in the northern and eastern parts of Turkey respectively $(22,23)$. Tuncbilek et al. found the overall neural tube defect 
rate throughout the country to be 3 per 1000 pregnancies (24). Although the reason for the comparatively lower incidence of neural tube defects in the Aegean region of Turkey has not yet been clarified, we postulated that the diet rich in folic acid may be a factor.

Our study has a few limitations. First, it is a hospital based study with a relatively small sample size. Second, these women were not followed during pregnancy and further micronutritional status cannot be evaluated. However, this study pointed out that there are several problems which need to be clarified and evaluated in further studies regarding micronutritional supplementation during pregnancy in our country. Although the results cannot reflect the whole population, they are valuable enough to stimulate a debate for micronutritional supplementation during pregnancy in our country.

In conclusion, the present study shows that subclinical iron and vitamin B12 deficiency is a hidden risk for pregnant women living in regions where a vegetable based diet is common. Because neural tube defect is an infrequent entity, prospective longitudinal studies with larger series are required in order to evaluate the effects of nutritional habits on the developing fetus. The necessity for vitamin B12 supplementation needs to be confirmed with prospective randomized trials from different regions of our country before the introduction of a fortification program for prevention of neural tube defect. Until that time, since it plays a role in the etiology of neural tube defects, concomitant vitamin B12 supplementation may be considered preconceptionally in places where a vegetable based diet is common.

\section{Conflict of interest}

No conflict of interest was declared by the authors.

\section{References}

1. Allen LH. Pregnancy and iron deficiency: unresolved issues. Nutr Rev 1997; 55: 91-101. [CrossRef]

2. Lumpy J, Watson L, Watson M, Bower C. Periconceptional supplementation with folate and/or multivitamins for preventing neural tube defects. Cochrane Database Syst 2001; Rev CD001056.

3. Honein MA, Paulozzi LJ, Mathews TJ, Erickson JD, Wong LY. Impact of folic acid fortification of the US food supply on the occurrence of neural tube defects. JAMA 2001; 285: 2981-6. [CrossRef]

4. Ray JG, Blom HJ. Vitamin B12 insufficiency and the risk of fetal neural tube defects. QJM 2003; 96: 289-95. [CrossRef]

5. Ray JG, Meier C, Vermeulen MJ, Boss S, Wyatt PR, Cole DE. Association of neural tube defects and folic acid food fortification. Lancet 2002; 360: 2047-8. [CrossRef]

6. Ray JG, Wyatt PR, Thompson MD, Vermeulen MJ, Meier C, Wong PY, et al. Vitamin B12 and the risk of neural tube defects in a folicacid-fortified population. Epidemiology 2007; 18: 362-6. [CrossRef]
7. Shane B. Folic acid, vitamin B12 and vitamin B6. In Biochemical and Physiological Aspects of Human Nutrition. In: M Stipanuk (ed). Philadelphia: W.B Saunders Company 2001; 483-518.

8. Income and living conditions survey 2009. Turkish statistical institude 28-2-2011. www.tuik.gov.tr

9. Micronutrient deficiencies iron deficiency anemia (http://www. who.int/nutrition/topics/ida/en/index.html)

10. WHO. The prevalence of anemia in women: a tabulation of available information. Geneva: Maternal Health and Safe Motherhood Program, World Health Organization: 100, 1990.

11. Ackurt F, Wetherlit H, Loker M, Hacibekiroglu M. Biochemical assessment of nutritional status in pre and post natal Turkish women and outcome of pregnancy. Eur J Clin Nutr 1995; 49: 613-22.

12. Karaoglu L, Pehlivan E, Egri M, Deprem C, Gunes G, Genc MF, et al. The prevalence of nutritional anemia in pregnancy in an east Anatolian province, Turkey. BMC Public Health 2010; 10: 329. [CrossRef]

13. Varela-Moreiras G, Murphy MM, Scott JM. Cobalamin, folic acid and homocysteine. Nut Rev 2009; 67: 69-72. [CrossRef]

14. Kirke PN, Molloy AM, Daly LE, Burke H, Weir DG, Scott JM. Maternal plasma folate and vitamin B12 are independent risk factors for neural tube defects. Q J Med 1993; 86: 703-8.

15. Zeteroglu S, Ustun Y, Engin-Ustun Y, Zeteroglu U, Karayel M. Serum Folic acid levels in women with recurrent early pregnancy loss. JTGGA 2003; 4: 36-7.

16. Mahmoud AM, Elkattan EA, Eldaly AAL, Omran EF, Mandour IM. A Comparative Study between Folate and Vitamin B12 serum levels in Preeclamptic Versus Normotensive Pregnant women in Correlation with Uterine and Umbilical Artery Doppler Findings and Pregnancy Outcome. JTGGA 2009; 10: 152-7.

17. Afman LA, Van Der Put NM, Thomas CM, Trijbels JM, Blom HJ. Reduced vitamin B12 binding by transcobalamin II increases the risk of neural tube defects. Q J Med 2001; 94: 159-66. [CrossRef]

18. House JD, March SB, Ratnam S, Ives E, Brosnan JT, Friel JK. Folate and vitamin B12 status in Newfoundland at their first prenatal visit. CMAJ 2001; 162; 1557-9.

19. Garcia-Casal MN, Osorio C, Landaeta M, Leets I, Matus P, Fazzino F, et al. High prevalence of folic acid and vitamin B12 deficiencies in infants, children, adolescents and pregnant women in Venezuela. Eur J Clin Nutr 2005; 59: 1064-70.

20. Posaci C, Celiloglu M, Karabacak O. The epidemiology of neural tube defects in Izmir, Turkey. Int J Gynecol Obstet 1992; 39: 135-8. [CrossRef]

21. Caglayan S, Kayhan B, Mentesoglu S, Aksit S. Changing incidence of neural tube defects in Aegean Turkey. Paediatr Perinat Epidemiol 1989; 3: 62-5.

22. Mocan H, Bozkaya H, Mocan MZ, Furtun EM. Changing incidence of anencephaly in the Eastern Black Sea Region of Turkey and Chernobyl. Paediatr Perinat Epidemiol 1990; 4: 264-8. [CrossRef]

23. Güvenc H, Uslu MA, Güvenc M, Ozekici U, Kocabay K, Bektaş S Changing trend of neural tube defects in Eastern Turkey. Epidemiol Community Health 1993; 47: 40-1.

24. Tuncbilek E, Boduroglu K, Alikasifoglu M. Neural tube defects in Turkey: prevalence, distribution and risk factors. Turk J Pediatr 1999; 41: 299-305. [CrossRef] 